\title{
ON THE OCCURRENCE ÖF A TOMATO DISEASE IN PUERTO RICO RESEMBLING BIG BUD (CHLOROGENOUS AUSTRALIENSTS Hol.)
}

\section{A. ALVAREZ-GARCIA ${ }^{1}$ AND JOSE ADSUAR ${ }^{2}$}

\section{INTRODUCTION}

This paper is a preliminary report on the occurrence of a tomato disease in Puerto Rico resembling Big Bud as described in Australia (1).

Big Bud of tomato in Puerto Rico was reported by the senior author since January 1945. The disease appeared among tomato plants grown experimentally in the fields of the Station.

The amount of diseased plants at that time was very small, 16 plants out of 3040 , that is, approximately $0.5 \%$, showed disease symptoms. During the fall and winter months of October 1945 to January 1946, 31 plants out of 1,800 or $1.6 \%$ appeared diseased and in the January-April, 1946 growing season, 236 plants out of 1,600 or $14 \%$ showed various stages of Big Bud infection.

Rainfall registered during each corresponding growing season was:

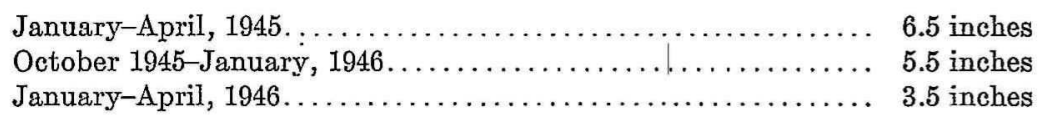

There was apparently a negative correlation, between amount of rainfall and increment of the disease. In all probability this could be ascribed to a gradual increase in virus reservoirs or in a greater population of a possible insect vector associated with the transmission of the viral agent (fig. 1).

SYMPTOMS OF THE DISEASE

The first noticeable symptom in tomato is characterized by a virescence of the young leaves and a peculiar stiffness and retardation of development of the young shoots. A rolling of the margins of older leaves is also very conspicuous (fig. 2).

When infection occurs in young tomato plants, the characteristic, generalized symptom is a marked retardation of growth of the plant, thickening of stem and branches, and proliferation of leaf buds, with subsequent atrophy of the newly formed leaves (fig. 3). The plant if infected very young ceases to grow, no leaf development occurs and the thickened stem

1 Plant Pathologist, Plant Pathology Department.

2 Plant Pathologist, Plant Pathology Department. 
DISEASED PLANTS PERGENT

JAN-APRIL' $\triangle 5$

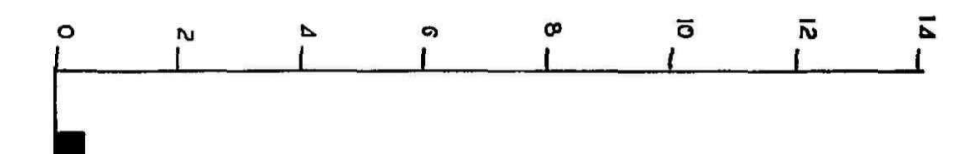

OCT-JAN' $\triangle 6$

JAN - APRILISG

JAN- APRILISG

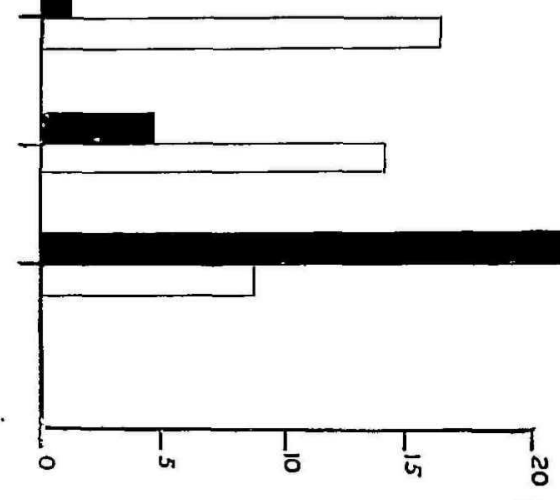

RAINFALL IN INCHES $\square$ -

Frg. 1. Per cent of Big Bud diseased plants and number of inches of rainfall observed during the various growing seasons.

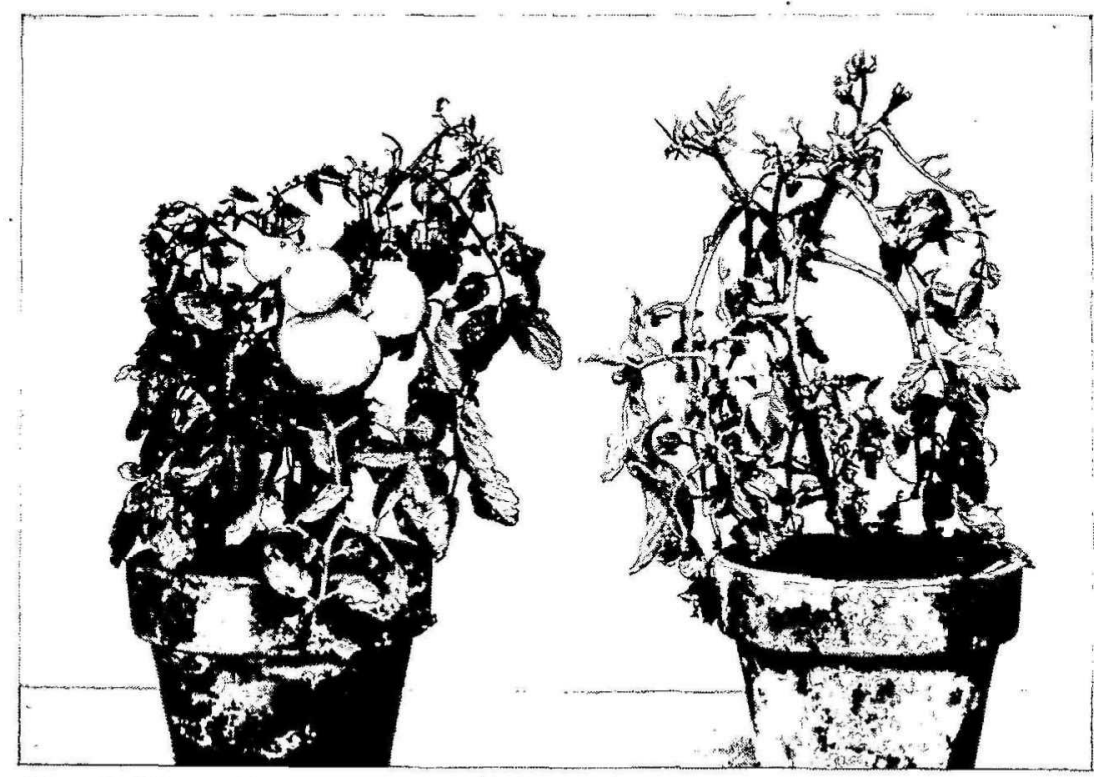

FrG. 2. Diseased tomato plants of the variety Bounty, showing leaf virescence, atrophy and stiffness of young leaves, and rolling of old leaves. Plant at the left showing infection. Plant at the right showing early infection at time of flowering. Note upright and vertical flower truss, enlargement of sepals and abortive fruits. 
and branches become yellowish. In extreme cases the whole plant structure is completely denuded of foliage (fig. 4).

When infection occurs at flowering time, the young flowers show very marked enlargement of the sepals which become thickened, somewhat oval in cross section and flattened on the upper side. The flowers assume an abnormal, upright position in contrast to the curved dorwnward position

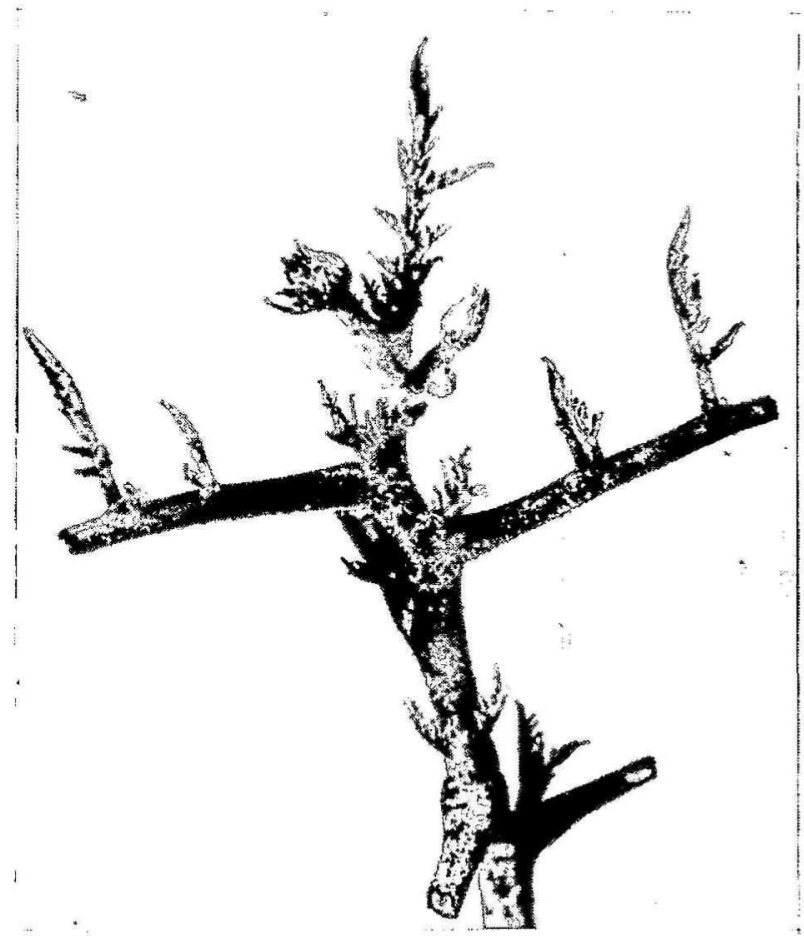

FIG. 3. Enlarged view of apical growth of an early infected tomato plant showing somewhat enlarged flower buds, proliferation of leaf buds, atrophy and stiffness of young leaves.

of flowers in normal plants (fig. 5). Young infected flowers show atrophy of stamens and ovary and are sterile; if fruit has already been formed before infection, its growth is checked and necrosis follows. Enlargement of the calyx, as reported from Australia, does not occur.

\section{TRANSMISSION STUDIES}

Attempts by various workers to transmit mechanically the tomato Big Bud virus ( $C$. australiensis) have met with failure. Transmission has been possible through grafting of buds and scions taken from diseased tomato 
plants and also by means of the leaf-hopper, Thamnotettix argentata Evans (2).

Cranberry false blossom virus (C. vaccinnii Hol.) when transferred to tomato plants, produces a symptomatology resembling very closely that

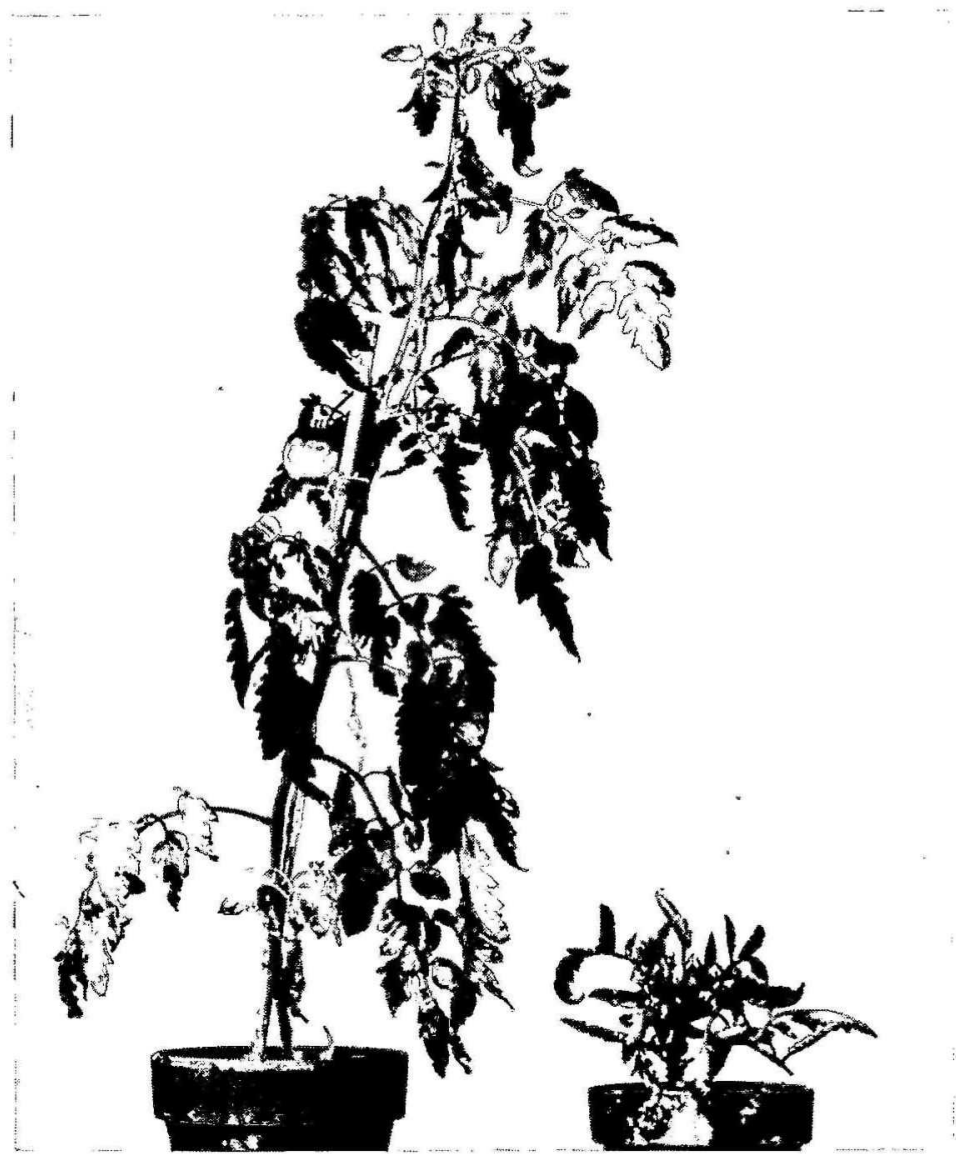

Frg. 4. Two young tomato plants, variety Marglobe, infected with Big Bud virus. Plants at the left showing normal growth. Plant at the right, early infected and showing marked dwarfiness. Both plants were of the same age.

of tomato Big Bud. This viral entity has been transferred either by grafting, by way of the parasitic phanerogam (Cuscuta campestris Yuncker L.), or by the insect vector, Euscelis striatulus (Fall). This type of Big Bud virus has also been transmitted by grafting to Vinca rosea L., tomato, potato, Turkish tobacco and Nicotiana glutinosa L. (3). 
Experiments initiated at this Station demonstrated the unsuccessful mechanical transmission of the virus. Transfer of the infectious entity has been obtained only by means of grafting. Experiments conducted during March and April 1945, by budding, side grafting and inarching, revealed that transmission is always obtained when union of scion and host tissue has occurred. The amount of infection fluctuated from 60 to $80 \%$ in young, fast growing tomato plants, variety Marglobe. Best results were obtained when buds were taken from diseased plants showing well advanced symptoms of the Big Bud disease. Transmission through C. filiformis, a parasite

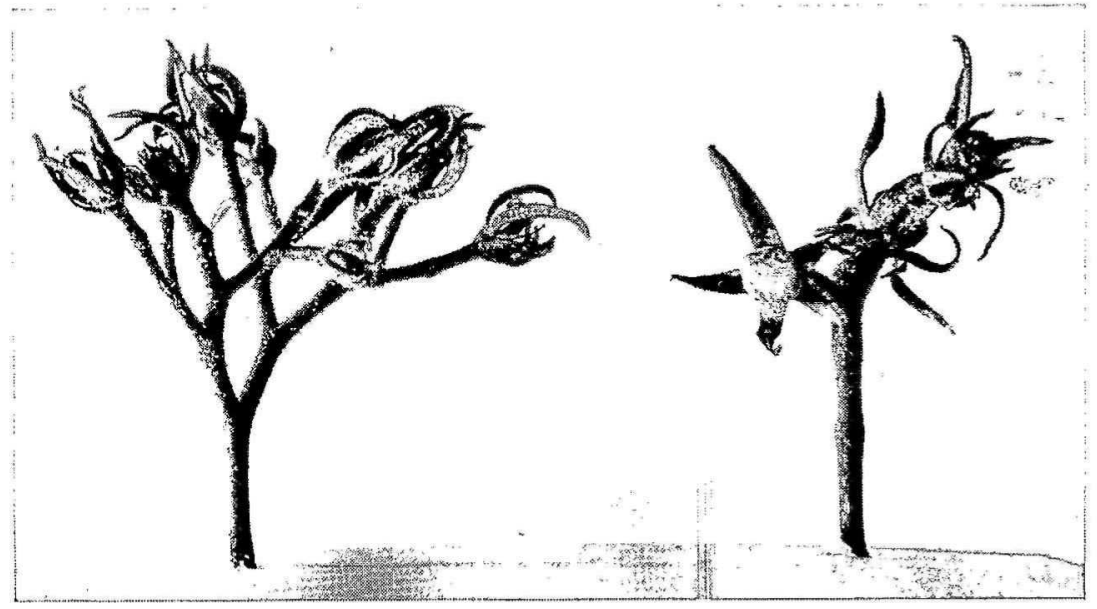

FIG. 5. Flower truss showing abortive fruits

rather endemic in the Island and by way of possible insect vectors has, so far, met with failure.

Symptoms of infection in grafted plants were noticeable within 30 to 40 days after grafting. This conforms very closely with the incubation period (28 to 56 days) for C. australiensis reported by Samuel, Bald and Earley in Australia.

\section{CONCLUSIONS AND SUMMARY}

The Puerto Rican type of tomato Big Bud disease is similar to that reported from Australia.

The main difference in symptomatology lies in the absence of a pronounced bladder-like hypertrophy of the calyx of virus invaded flowers. Other slight differences between the Puerto Rican and Australian type of 
Big Bud could be possibly due to:

1) the existence of two distinct strains of the virus.

2 ) the influence of local environment on symptom manifestation.

\section{LITERATURE CITED}

1. Samuel, G., Bald, J. O. and Earley, C. M. "Big Bud" A Virus Disease of the Tomato. Phytopath. 23: 641-653, 1933.

2. Hill., A. V. Jour. Council Sci. Ind. Res. 16: 2, 85-90, 1943.

3. Kunkel, L. O. Studies on Cranberry False Blossom. Phytopath. 35: 805-822, 1945. 